\title{
The Influence of Ownership Structure, Leverage, Profitability, Company Size, and Audit Quality on Tax Avoidance in Indonesia
}

\author{
Putu Wulandari ${ }^{1,{ }^{*}}$ Made Sudarma ${ }^{2}$ \\ 1,2 Brawijaya University, Indonesia \\ "Corresponding author. Email: primawulandari@ub.ac.id
}

\begin{abstract}
Taxes are one of the most dominant revenues in the APBN. However, the fact is that the tax potential is not being utilized properly. It is due to the low level of the tax ratio in Indonesia compared to other ASEAN countries. The low level of the tax ratio is due to the prevalence of tax evasion and even tax evasion. This study aimed to analyze the effect of government ownership, family, institutional, foreign, leverage, profitability, firm size, and audit quality on tax avoidance. The method used in this study is the Partial Significant Test (T-Test). The results of this study are government and institutional ownership structure have a positive effect on tax avoidance. Meanwhile, family, foreign ownership structure, company leverage, profitability, company size, and audit quality do not affect tax avoidance.
\end{abstract}

Keywords: Ownership Structure, Profitability, Leverage, Audit Quality, Company Size, Tax Avoidance.

\section{INTRODUCTION}

Tax is a mandatory contribution paid to the state by individuals or entities that have been regulated by law. Taxes have an important role, namely as the main revenue sector in the APBN (State Revenue and Expenditure Budget). According to [1], recorded, the 2020 State Budget of the total state revenue is $\mathrm{Rp}$ 2,233.2 trillion, consisting of tax revenues of $\mathrm{Rp}$ 1,865.7 trillion, non-tax revenues of Rp 367 trillion, and grant receipts of 0.5 trillion. However, in fact, the potential for tax as state revenue is not in accordance with taxpayer compliance. It is supported by previous data shown [1] which notes that the tax ratio in Indonesia is only around $10-11 \%$. Indonesia's tax ratio in 2017 was $10.7 \%$, in 2018 it was $11.4 \%$, in 2019 it was $11,1 \%$ and in 2020 it was $11,6 \%$. Based on these data, Indonesia is still far behind other countries in the ASEAN region such as the Philippines at $14.2 \%$, Malaysia at $13.1 \%$, and Thailand at $14.8 \%$ as previously shown [1]. The low tax ratio in Indonesia is also caused by the low compliance of taxpayers, including tax evasion.

On the other hand, the government has made regulations to avoid taxes legally without violating tax laws by taking advantage of tax avoidance loopholes in the tax law. The tax avoidance action can provide direct benefits such as increasing cash flow and net income after tax expense presented in the financial statements and increasing book income, after-tax cash flow, and net assets in the company's financial statements [2]. Tax avoidance behavior can be explained by agency theory at the corporate level. Ownership structure can be one factor in reducing information asymmetry from the management for opportunistic actions. Management's opportunistic actions can be in the form of making decisions that are not in accordance with the shareholders' objectives. Ownership structure can also affect the company's financial performance and decision-making. A centralized ownership structure has the potential to cause tax avoidance.

Company management is very likely to choose tax avoidance practices and strategically choose to increase profitability. Separation of ownership affects corporate tax practices [3]. Differences in interests between owners and agents can affect corporate tax compliance. Management can do tax avoidance to increase their compensation through good financial performance. Previous studies related to tax ownership and avoidance such as research [4] which examined government, family, and foreign ownership 
effects on tax avoidance. Furthermore, research by [5] shows government ownership and control versus institutional ownership significantly affects tax avoidance. The strategy to maximize management's welfare that deviates from the company's goals is what creates problems because of inappropriate policies. These problems can provide an opportunity for management to manipulate the amount of the company's taxable income so that the tax burden that the company must pay becomes lower [6].

Reporting the results of the company's financial statements where financial ratios are compared with the level of tax aggressiveness that agents may carry out can be a way to control agent actions in tax management [6]. [7] stated that the compensation and benefits received by management affect tax avoidance. Family companies are most likely to benefit from tax avoidance from corporate control because company owners can control share ownership with voting rights in decision-making [8]. Owner control in the company is also supported by the phenomenon where in Indonesia, investor protection tends to be weak, the controlling holder uses this to practice tax saving. Maximizing company resources to gain profits and political connections is the goal of tax planning in companies controlled by government ownership [9]. Companies controlled by the government are very likely to pay taxes at low rates because of political connections owned by companies [10] states that companies with political connections are positively related to tax aggressiveness actions.

Political connections will make companies more aggressive in tax planning, so there will likely be a decrease in public transparency [11]. Government companies are more aggressive in committing tax evasion due to the weak enforcement of sanctions and regulations in Indonesia. Manager's strategy in tax avoidance has a negative effect on shareholder decision making so that it has a bad impact on the company's image in the eyes of investors. The desire to maximize the welfare of managers and shareholders is also a motivation for managers to carry out tax avoidance strategies. [12] state that institutional ownership in companies has an impact on corporate tax planning policies. Research [13] states that the amount of share ownership by foreign investors has a positive effect on the level of tax avoidance by the company. Regarding foreign ownership, the study results also show that banks owned by foreign investors pay lower taxes in some countries.
One of the risks that will be faced by the company if obtaining funding in the form of high debt will result in the company's obligation to pay high debt interest. The increase in the company's leverage will increase the interest costs arising from the debt, thus the tax burden will decrease. On the other hand, the decrease in the level of taxes that must be paid is certainly very meaningful for companies with high taxes. Associated with the company's financial performance, not only the level of leverage that can also affect the company's tax, but the company's performance in generating profits can also affect the management's decision to do tax avoidance. The profitability ratio measures the company's performance to generate profits. Tax planning is very likely to occur when companies evaluate their performance with profitability ratios to plan profits for each period determined based on the targets to be achieved. An increase in the amount of profit earned will also increase the amount of income tax, so this is what encourages companies to take tax avoidance actions to avoid increasing the number of tax costs

Regarding the company's size, large companies tend to do tax avoidance because the amount of company profit is positively proportional to the tax burden. In addition, large companies' profits are also more stable.

In conducting audits, of course, many companies entrust their reports to be audited by the Big Four Public Accounting Firms (KAP) because they are considered to be of higher quality and more capable. The big four KAP is also believed to be able to limit earnings management practices where is one of the activities of tax avoidance. Therefore, the better the quality of the audit produced, the less tendency the company has to manipulate the company's profits, and there will be minimal tax evasion.

Therefore, this study raises the problem of how does the analysis of government, family, institutional, foreign ownership, leverage, profitability, firm size, and audit quality affect tax avoidance? Thus, the purpose of this study is to analyze the effect of government, family, institutional, foreign ownership, level of leverage, level of profitability, firm size, and audit quality on tax avoidance?

The hypothesis in this study are:

H1: Family ownership has a positive effect on tax avoidance 
H2: Government ownership has a positive effect on tax avoidance

H3: Institutional ownership has a positive effect on tax avoidance

H4: foreign ownership has a positive effect on tax avoidance

H5: Leverage has a positive effect on tax avoidance

H6: Profitability has a positive effect on tax avoidance

H7: Firm size has a positive effect on tax avoidance

H8: Audit quality has a negative effect on tax avoidance.

\section{RESEARCH METHOD}

This study uses a quantitative approach based on research theories and hypotheses that aim to answer research questions regarding whether there is a relationship between each variable. This study examines the influence of corporate ownership structure, leverage, profitability, firm size, and audit quality on tax avoidance. The secondary data used in this study was obtained from the annual reports of companies listed on the Indonesia Stock Exchange based on predetermined criteria from 2017-2019. The sample in this study was 250 shares of companies listed on the Indonesian stock exchange. Quantitative data used in this study are financial statements and company annual reports.

\subsection{Variable Measurement}

The dependent variable in this study is tax avoidance. In this study, the measurement of tax avoidance uses the Cash ETR measurement. This model was also carried out in several previous studies by [14]. With the following formula:

$$
\text { Cash ETR }=\frac{\text { cash taxes paid }}{\text { pre }- \text { tax income }}
$$

Measurement of family ownership is measured using the largest final controlling share ownership Dummy. If the ultimate controlling share ownership is by the name of an individual in one family or a family group, it will be assigned a value of 1 and otherwise 0 . The measurement of government ownership used in this study was previously also used by several previous studies, including research conducted by [15].
Government Ownership

$=\frac{\text { the number of shares of the government }}{\text { total outstanding shares at the end of the year }}$

Measurement of institutional ownership like this is also used in research conducted as previously shown [5].

\section{Institutional Ownership}

$=\frac{\text { the number of shares of the instituional }}{\text { total outstanding shares at the end of the year }}$

Foreign ownership in this study uses the percentage of foreign share ownership as this is also used in research conducted as previously shown [13].

$$
\begin{aligned}
& \text { Foreign Ownership } \\
& =\frac{\text { the number of shares of the foreign }}{\text { total outstanding shares at the end of the year }}
\end{aligned}
$$

Managerial Ownership is calculated by the following formula [16].

Managerial Ownership

$$
=\frac{\text { the number of shares of the managerial }}{\text { total outstanding shares at the end of the year }}
$$

In measuring this audit quality variable, a dummy variable is used :

$0=$ Companies that use non-big four KAP services $1=$ Companies that use big four KAP services

A company's profitability is calculated using return on assets (ROA). The greater the value of a company's ROA, the greater the value of the company's net income and the better the management of company assets in obtaining profitability. According to [12] and [14] good company profitability tends to have a higher level of effective tax rates. Thus the ROA coefficient can indicate low tax avoidance.

$$
\text { Return on Assets }=\frac{\text { pre }- \text { tax income }}{\text { total assets }}
$$

Leverage aims to calculate funding from third parties used by the company. The greater the value of the company's debt, the lower the company's ETR value, thus the company's leverage coefficient can show a positive effect on tax avoidance.

$$
\text { Leverage }=\frac{\text { long }- \text { term debt }}{\text { total assets }}
$$

The size of the company can be measured by the total assets / large assets of the company by using the value calculation with the natural logarithm (Logn) of Total Assets [17]. 


$$
\text { SIZE }=(\text { Total Assets })
$$

\subsection{Data Analysis Technique}

Statistical analysis used in this study is the t Test. The form of the regression model used in this study is as follows:

$$
\begin{aligned}
\mathrm{CTA}_{i . t}=\alpha_{i}+\beta_{1} & \text { Family }_{i . t}+\beta_{2} \operatorname{Gov}_{i . t} \\
& +\beta_{3} \text { Institutional }_{i . t} \\
& +\beta_{4} \text { Foreign }_{i . t} \\
& +\beta_{5} \text { Audit Quality }_{i . t}+\beta_{6} \text { Profit }_{i . t} \\
& +\beta_{7} \operatorname{Lev}_{i . t}+\beta_{8} \text { Size }_{i . t}
\end{aligned}
$$

\section{RESULTS AND DISCUSSION}

Table 1. Partial Significance Test (t-Test)

\begin{tabular}{|l|c|c|c|c|c|}
\hline \multicolumn{1}{|c|}{ Coefficients } & \\
\hline \multirow{1}{*}{ Model } & \multicolumn{2}{|c|}{$\begin{array}{c}\text { Unstandardized } \\
\text { Coefficients }\end{array}$} & $\begin{array}{c}\text { Stand } \\
\text { ardize } \\
\mathrm{d} \\
\text { Coeffi } \\
\text { cients }\end{array}$ & $\mathrm{t}$ & Sig. \\
\cline { 2 - 6 } & $\mathrm{B}$ & $\begin{array}{c}\text { Std. } \\
\text { Error }\end{array}$ & Beta & & \\
\hline (Constant) & 0.401 & 0.245 & & 1.640 & .102 \\
\hline $\begin{array}{l}\text { Family } \\
\text { Ownership }\end{array}$ & -.150 & .075 & -.225 & -1.994 & 0.047 \\
\hline $\begin{array}{l}\text { Government } \\
\text { Ownership }\end{array}$ & 0.110 & 0.103 & -0.16 & 2.523 & 0.043 \\
\hline $\begin{array}{l}\text { Institutional } \\
\text { Ownership }\end{array}$ & 0.153 & 0.065 & -0.32 & 2.734 & 0.005 \\
\hline $\begin{array}{l}\text { Foreign } \\
\text { Ownership }\end{array}$ & -121 & 0.070 & -0.18 & -1.720 & 0.087 \\
\hline Leverage & -0.09 & 0.053 & -155 & -1.801 & 0.073 \\
\hline ROA & -0.89 & 0.212 & -0.29 & -4.216 & 0.000 \\
\hline $\begin{array}{l}\text { Company } \\
\text { Size }\end{array}$ & 0.002 & 0.008 & 0.021 & 0.245 & 0.806 \\
\hline Audit Quality & 0.019 & 0.023 & 0.057 & 0.837 & 0.403 \\
\hline Dependent Variable: CETR & & & \\
\hline
\end{tabular}

Based on the results of the t-test in the table above, it can be explained as follows.

1. The family ownership has a value of sig. $<\alpha$ $(0.047<0.05)$, however, the beta coefficient value shows a negative direction, so $\mathrm{H} 1$ is rejected. This means that the family ownership has no positive effects on tax avoidance. This is in contrast with the results of research by [18-20] which state that family ownership has a positive influence on tax avoidance. This result is in accordance with the results of research by [14, 21-22] which state that family ownership does not affect tax avoidance.

2. The government ownership variable has a value of sig. $<\alpha(0.043<0.05)$. The beta coefficient value shows a positive direction, thus $\mathrm{H} 2$ is accepted. This means that the government ownership variable has positive effects on tax avoidance. This result is in accordance with the results of research by [23-24] which state that government ownership has a positive effect on tax avoidance. In contrast with the results of research by [19], [22], and [25] which state that government ownership does not affect tax avoidance.

3. The Institutional ownership variable has a value of sig. $<\alpha(0.005<0.05)$, The beta coefficient value shows a positive direction, thus $\mathrm{H} 3$ is accepted. This means that institutional ownership variables have positive effects on tax avoidance. This result is in accordance with the results of research by [21, 26-27] which state that institutional ownership has a positive influence on tax avoidance. In contrast to the results of research by [28] which states that institutional ownership does not affect tax avoidance.

4. The foreign ownership variable has a value of sig. $>\alpha$ $(0.087>0.05)$ and beta coefficient value shows a negative direction. Thus $\mathrm{H} 4$ is rejected. This means that the foreign ownership variable does not affect tax avoidance. This is consistent with the results of research by [29-30] which state that foreign ownership has a negative effect on tax avoidance. In contrast to the results of research by [31] which state that foreign ownership affects tax avoidance.

5. The leverage variable has a value of sig. $>\alpha$ $(0.073>0.05)$, beta coefficient value shows a negative direction. Thus H5 is rejected. This means that the leverage variable has no positive effects on tax avoidance. This is in accordance with the results of research as previously shown [20] and [27] which state that leverage has a negative effect on tax avoidance. In contrast to the results of research by [3233] which state that leverage affects tax avoidance.

6. The profitability variable has a value of sig. $<\alpha$ $(0.000<0.05)$, however, the beta coefficient value shows a negative direction. Thus H6 is rejected. This means that profitability has no positive effects on tax avoidance. This is in contrast with the results of research by [21] and [32] which state that profitability has a positive effect on tax avoidance. This result is in accordance with the results of research by [34] which states that profitability does not affect tax avoidance.

7. The firm size variable has a value of sig. $>\alpha$ $(0.806>0.05)$. Thus $\mathrm{H} 7$ is rejected. This means that the firm size has no positive effects on tax avoidance. This is in accordance with the results of research by [35-36] which state that firm size has a negative effect on tax avoidance. In contrast to the results of research as 
previously shown [32-33] which state that company size affects tax avoidance.

8. The audit quality variable has a value of sig. $>\alpha$ $(0.403>0.05)$. Thus $\mathrm{H} 8$ is rejected. This means that the audit quality has no positive effects on tax avoidance. This is consistent with the results of research by [3739] which state that audit quality has a negative effect on tax avoidance.

\section{CONCLUSION}

The results of this study indicate that from 250 samples of companies tested, it is stated that only government and institutional ownership have a positive effect on tax avoidance. Meanwhile, family, foreign ownership structure, company leverage, profitability, company size, and audit quality have no positive effect on tax avoidance. This indicates that not all types of ownership structures affect tax avoidance. The contribution of this research to family businesses during the COVID-19 pandemic is an understanding of tax avoidance practices that can ultimately harm the company in the form of fines or sanctions for these actions.

\section{AUTHORS' CONTRIBUTIONS}

In this study, Made Sudarma contributed to compiling the introduction by exploring the phenomenon of tax avoidance in Indonesia, developing research hypotheses and developing research method designs. The contribution Putu Wulandari are to determine the research sample using sampling techniques, collecting data, and analyzing data and arranging a discussion of research results.

\section{ACKNOWLEDGMENTS}

The author's appreciation is addressed to Economics and Business Faculty Universitas Brawijaya, which funded this research.

\section{REFERENCES}

[1] Kementerian Keuangan Republik Indonesia, Anggaran Pendapatan dan Belanja Negara, 2020. Available https://www.kemenkeu.go.id/apbn2020

[2] Rego, S. O., and Wilson, R., Executive Compensation, Tax Reporting Aggressiveness, and Future Firm Performance, In Working Paper, University of Lowa, 2011.
[3] Badertscher, B. A., Katz, S. P., and Rego, S. O., The separation of ownership and control and corporate tax avoidance, Journal of Accounting and Economics, 2013, doi: 10.1016/j.jacceco.2013.08.005.

[4] Annuar, H. A., Salihu, I. A., and Obid, S. N. S., Corporate Ownership, Governance and Tax Avoidance: An Interactive Effects, Procedia Social and Behavioral Sciences, 2014, doi: 10.1016/j.sbspro.2014.11.063.

[5] Ying, T., Wright, B., and Huang, W., Ownership structure and tax aggressiveness of Chinese listed companies, International Journal of Accounting and Information Management, 2017, doi: 10.1108/IJAIM-07-2016-0070.

[6] Nugraha, N. B., and Meiranto, W., Pengaruh Corporate Social Responsibility, Ukuran Perusahaan, Profitabilitas, Leverage Dan Capital Intensity Terhadap Agresivitas Pajak, In Diponegoro Journal of Accounting, vol. 4, no. 4, pp. 1-14, 2015

[7] Tandean, V. A., and Winnie., The Effect of Good Corporate Governance on Tax Avoidance, Asian Journal of Accounting Research, 2016, doi: 10.1108/AJAR-2016-01-01-B004.

[8] La Porta, R., Lopez-de-Silanes, F., \& Shleifer, A., Corporate ownership around the world, Journal of Finance, 1999, doi: 10.1111/00221082.00115 .

[9] Wang, Q., Wong, T. J., and Xia, L., State ownership, the institutional environment, and auditor choice: Evidence from China, Journal of Accounting and Economics, 2008, doi: 10.1016/j.jacceco.2008.04.001.

[10] Kim, C and Zhang, L., Corporate political connections and tax aggressiveness, Contemporary Accounting Research, vol. 33, no. 1, pp. 78-114.

[11] $\mathrm{Yu}, \mathrm{J}$ and $\mathrm{Yu}, \mathrm{Y}$., Investor sentiment and the mean-variance relation, Journal of Financial Economics, vol. 100, pp. 367-381, 2011.

[12] Khurana, I. K., and Moser, W. J., Institutional shareholders' investment horizons and tax avoidance, Journal of the American Taxation Association, 2013, doi: 10.2308/atax-50315.

[13] Salihu, I. A., Annuar, H. A., and Sheikh Obid, S. N., Foreign investors' interests and corporate tax avoidance: Evidence from an emerging 
economy, Journal of Contemporary Accounting and Economics, 2015, doi: 10.1016/j.jcae.2015.03.001.

[14] Chen, S., Chen, X., Cheng, Q., and Shevlin, T., Are family firms more tax aggressive than nonfamily firms?, Journal of Financial Economics, vol. 95, no. 1, pp. 41-61, 2010.

[15] Zeng, T., Ownership Concentration, State Ownership, and Effective Tax Rates: Evidence from China's Listed Firms*, Accounting Perspectives, 2010, doi: 10.1111/j.19113838.2010.00014.x.

[16] Pramudito, Batara Wiryo and Sari, Maria M. Ratna, Pengaruh Konservatisme Akuntansi, Kepemilikan Manajerial dan Ukuran Dewan Komisaris terhadap Tax Avoidance, E-Journal Akuntansi Universitas Udayana, vol. 13, no. 3, pp. 705-722, 2015.

[17] Abdillah, W and Hartono, Partial Least Square (PLS). Yogyakarta: Penerbit Andi, 2015.

[18] Wirdaningsih, et al., Pengaruh Kepemilikan Keluarga Terhadap Penghindaran Pajak Dengan Efektivitas Komisaris Independen dan Kualitas Audit Sebagai Pemoderasi, Jurnal Akuntansi, vol. 7, no. 1, pp. 15-29, 2018.

[19] Purnomo, L. C., Pengaruh Struktur Kepemilikan Perusahaan Terhadap Tindakan Pajak Agresif, Jurnal BPPK: Badan Pendidikan dan Pelatihan Keuangan, vol. 9, no. 1, pp. 99-108, 2016.

[20] Indirawati, T and Dwimulyani, S., Pengaruh Kepemilikan Keluarga dan Leverage Terhadap Tax Avoidance Dengan Menggunakan Strategi Bisnis Sebagai Variabel Moderasi, Prosiding Seminar Nasional Pakar ke II, pp. 2441-2448, 2019 .

[21] Wijayani, R., Pengaruh Profitabilitas, Kepemilikan Keluarga, Corporate Governance dan Kepemilikan Institusional Terhadap Penghindaraan Pajak Di Indonesia (Studi Empiris Perusahaan Manufaktur Yang Terdaftar Di BEI Tahun 2012-2014), Jurnal Dinamika Ekonomi dan Bisnis, vol. 13, no. 2, pp. 181-192, 2016 .

[22] Rusydi, K., and Martani, D., Pengaruh Struktur Kepemilikan Terhadap Aggressive Tax Avoidance, Simposium Nasional akuntansi 17, Mataram, 2014.
[23] Adhikari, A., Derashid, C., and Zhang, H., Public policy, political connections, and effective tax rates: Longitudinal evidence from Malaysia, Journal of Accounting and Public Policy, vol. 25, no. 5, pp. 574-595, 2006.

[24] Riyadi, A., and Halim, A., Pengaruh Struktur Kepemilikan Pemerintah Terhadap Penghindaran Pajak: Studi Pada Perusahaan yang Terdaftar di Bursa Efek Indonesia, Unpublished Manuscript.

[25] Ha, N. T. T., and Phan, G. Q., The relationship between state ownership and tax avoidance level: empirical evidence from Vietnamese firms, Journal of Asian Business Strategy, vol. 7, no. 1, pp. 31-43, 2017.

[26] Putri, A and Lawita, F., Pengaruh Kepemilikan Institusional dan Kepemilikan Manajerial Terhadap Penghindaran Pajak, Jurnal Akuntansi dan Ekonomika, vol. 9, no. 1, pp. 68-75, 2019.

[27] Ngadiman and Puspitasari, W., Pengaruh Leverage, Kepemilikan Institusional, Dan Ukuran Perusahaan Terhadap Penghindaran Pajak (Tax Avoidance) Pada Perusahaan Sektor Manufaktur Yang Terdaftar Di Bursa Efek Indonesia 2010-2012, Jurnal Akuntansi, vol. XVII, no. 3, pp. 408-421, 2014.

[28] Pratomo, D., Pengaruh Kepemilikan Instituional, Komisaris Independen dan Komite Audit Terhadap Penghindaran Pajak, Jurnal Akuntansi Kajian Ilmiah Akuntansi, vol. 8, no. 1, pp. 91103, 2021.

[29] Hidayat, M and Mulda, R., Pengaruh Book Tax Gap dan Kepemilikan Asing Terhadap Penghindaran Pajak dan Analisis Kebijakan Pemerintah Terkait Penghindaran Pajak, Dimensi, vol. 8, no. 3, pp. 404-418, 2019.

[30] Maisaroh, S and Setiawan, D., Kepemilikan Saham Asing, Dewan Komisaris Asing dan Direksi Asing Terhadap Penghindaran Pajak di Indonesia, Jurnal Akuntansi dan Bisnis, vol. 21, no. $1,2021$.

[31] Widawati, Pengaruh Struktur Kepemilikan, Kebijakan Perusahaan dan Risiko Bisnis Terhadap Tax Avoidance, Jurnal Ilmu dan Riset Akuntansi, vol. 8, no. 8, pp. 1-26, 2020.

[32] Aulia, I. and Mahpudin, E., Pengaruh profitabilitas, leverage, dan ukuran perusahaan terhadap tax avoidance, Akuntabel, vol. 17, no. 2, pp. 289-300, 2020 
[33] Barli, H., Pengaruh Leverage and Firm Size Terhadap Penghindaran Pajak (Studi Empiris Pada Perusahaan Sektor Property, Real Estate Dan Building Construction Yang Terdaftar Di Bursa Efek Indonesia Periode Tahun 20132017), Jurnal Ilmiah Akuntansi Universitas Pamulang, vol. 6, no. 2, pp. 223-238, 2018.

[34] Hidayat, W., Pengaruh Profitabilitas, Leverage Dan Pertumbuhan Penjualan Terhadap Penghindaran Pajak: Studi Kasus Perusahaan Manufaktur Di Indonesia, Jurnal Riset Manajemen dan Bisnis, vol. 3, no. 1, pp. 19-26, 2018.

[35] Dewi, P., Pengaruh Ukuran Perusahaan, Leverage, Profitabilitas dan Corporate Social Responsibility Terhadap Penghindaran Pajak (Tax Avoidance), E-Journal Akuntansi, vol. 21, no. 2, pp. 882-911, 2017.

[36] Indriani, D. and Juniarti, Pengaruh Ukuran Perusahaan, Umur Perusahaan, Pertumbuhan Penjualan, Dan Profitabilitas Terhadap
Penghindaran Pajak (Studi Empiris Pada Perusahaan Sub Sektor Farmasi Yang Terdaftar Di Bursa Efek Indonesia Periode 2016-2019), Sekolah Tinggi Ilmu Ekonomi Indonesia, 2020. Available at: http://repository.stei.ac.id/id/eprint/2123

[37] Mira and Purnamasari, W., Pengaruh Kualitas Audit Terhadap Tax Avoidance Pada Perusahaan Sektor Perbankan Yang Terdaftar di BEI Periode 2016-2018, Amnesty: Jurnal Riset Perpajakan, vol. 3, no. 2, pp. 211-226, 2020.

[38] Damayanti, F. and Susanto, T., Pengaruh Komite Audit, Kualitas Audit, Kepemilikan Institusional, Risiko Perusahaan dan Return On Assets Terhadap Tax Avoidance, Jurnal Bisnis dan Manajemen, vol. 5, no. 2, pp. 187-206, 2015.

[39] Pratomo, D., Pengaruh Kepemilikan Instituional, Komisaris Independen dan Komite Audit Terhadap Penghindaran Pajak, Jurnal Akuntansi Kajian Ilmiah Akuntansi, vol. 8, no. 1, pp. 91103, 2021. 